\title{
Familial isolated hyperparathyroidism
}

INSERM

\section{Source}

INSERM. (1999). Orphanet: an online rare disease and orphan drug data base. Familial isolated hyperparathyroidism. ORPHA:99879

A rare, hereditary, familial primary hyperparathyroidism disease characterized by primary hyperparathyroidism due to single or multiple parathyroid tumors in at least two firstdegree relatives in the absence of evidence of other endocrine disorders, tumors and/or systemic manifestations. 